\title{
Modeling saline water intrusion in Nagapattinam coastal aquifers, Tamilnadu, India
}

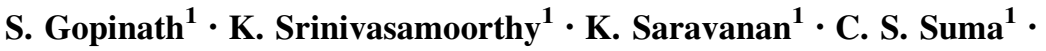 \\ R. Prakash ${ }^{1} \cdot$ D. Senthilnathan ${ }^{1} \cdot$ N. Chandrasekaran ${ }^{2} \cdot$ Y. Srinivas ${ }^{2}$. \\ V. S. Sarma ${ }^{3}$
}

Received: 12 November 2015/ Accepted: 17 November 2015/Published online: 11 December 2015

(C) Springer International Publishing Switzerland 2015

\begin{abstract}
Unexpected mistreatment of groundwater from coastal aquifers may possibly cause salt water intrusion in coastal aquifers. Coastal areas are mostly overpopulated with productive agricultural lands and expanded irrigated farming actions. Field and modeling studies were started to consider the special effects of possible seawater intrusion into the coastal aquifers. Groundwater levels were measured at 61 locations in Nagapattinam and Karaikal coastal region, identified flow direction pointing toward the coast with no major change in groundwater table. Groundwater samples were collected and analyzed for major ionic parameters, represented higher concentration of conductivity, total dissolved solids, sodium and chloride along the coastal parts of the study area. A computer package for the simulation of dimensional variable density groundwater flow, SEAWAT, has been used to model the seawater intrusion in the coastal aquifers of the study area. The model was stimulated to predict the amount of seawater incursion in the study area for a period of 50 years. The simulation results signify saline water intrusion mainly due to up coning of saline water owing to over drafting of groundwater.
\end{abstract}

Keywords Saline water intrusion - Coastal aquifers . Ionic ratios $\cdot$ SEAWAT modeling $\cdot$ Prediction

K. Srinivasamoorthy

krishnarajsrinivasamoorthy@gmail.com

1 Department of Earth Sciences, Pondicherry University, Puducherry 605 014, India

2 Centre for Geotechnology, Manonmaniam Sundarar University, Tirunelveli, Tamil Nadu 627012, India

3 National Geophysical Research Institute (CSIR), Hyderabad, Andhra Pradesh 500 007, India

\section{Introduction}

Seawater intrusion creates a protruding hydrological problem in several coastal areas of the world (Werner and Simmons 2008). This phenomenon occurs when the natural balance between fresh and sea water is troubled, which results in deterioration of fresh water resources (Xue et al. 1999). A number of mathematical and numerical models have been established and used to predict the site and movement of seawater intrusion. The models portray the interface of two different fluids (saline and fresh water) by sharp interface and variable density assumptions (Abd-Elhamid and Javadi 2011; Bobba 1993; Kopsiaftis et al. 2009). The sharp interface theory is applicable when the width of the transition zone is relatively small when compared with the aquifer thickness (Zheng 1990; Zheng and Wang 1999). (Fei Ding et al. 2014) attempted for saline water intrusion modeling in Liao Dong Bay Coastal Plain, China using SEAWAT-MODFLOW code to solve the density-dependent groundwater flow and solute transport governing equations and identified saline water intrusion up to $6.2 \mathrm{~km}$ inland and predicted for the next 40 years. (Gaaloul et al. 2012) identified saline intrusion in coastal aquifers of Tunisia using density-dependent miscible flow and transport modeling approach. (Surinaidu et al. 2014) used the SEAWAT modeling for saline water intrusion in Godavari delta region and projected the intrusion for the next 50 years. Numerous studies were put forth for saline water intrusion in different parts of the globe by (Guo and Langevin 2002; Langevin et al. 2003; Bakker et al. 2004; Guo and Bennett 1998a, b; Sindhu et al. 2012).

An attempt has been made in the coastal aquifers of Nagapattinam and Karaikal region to assess the ingress of saline water intrusion, where significant quantities of 
groundwater are drawn for various utilities like agriculture, industrial and domestic utilities (Gopinath et al. 2014) using numerical groundwater flow and solute transport model developed with SEAWAT code, using hydrogeological and hydrochemical data.

\section{Study area}

The area proposed for the study is situated in Nagapattianam and Karaikkal regions positioned along coastal Tamilnadu, India with a total spread of $1000 \mathrm{~km}^{2}$. It is located in the longitude between $79^{\circ} 01^{\prime} \mathrm{E}$ to $80^{\circ} 01^{\prime} \mathrm{E}$ and latitude between $10^{\circ} 85^{\prime} \mathrm{N}$ to $11^{\circ} 40^{\prime} \mathrm{N}$ with an average elevation of $20 \mathrm{~m}$ above mean sea level (Fig. 1). The most significant economic development of the area is agriculture, with major crops sown like paddy, sugarcane, coconut and plantains. The area is also occupied by fresh water aquaculture along the coastal parts of the study area. Industries like soap manufacturing, coir, Spinning Mill, petrochemical and sugar manufacturing are also located in the premises of the study area.

\section{Geology, hydrogeology and groundwater occurrences}

The geology of the area is mainly occupied by Quaternary sediments, defined as alluvial plain deposits of the river
Cauvery followed by fluvio-marine, deltaic plain deposits and marine coastal plain deposits. The fluvial deposits encompasses flood plain, flood basin, point bar, channel bar and palaeo channels with admixtures of sand, silt and clay. The deltaic plain includes palaeo tidal flats with clays, sands and sand ridges of grey brown sand. The southern part of the study area occupied by Pliocene deposits named as Karaikkal beds with admixtures of sand, clay and minor limestone (CGWB 1993). The thickness of the Quaternary sediments ranges between 1 to $50 \mathrm{~m}$ and 50 to $77 \mathrm{~m}$ in Pliocene formations (Fig. 1).

Important aquifer systems in the study area are the lower Miocene (LM) deeper aquifers and the Pliocene-Quaternary shallow (PQS) aquifers. Ground water occurs under water table, semi-confined and confined conditions. The thickness of the PQS aquifer ranges between 5 and $25 \mathrm{~m}$. The thickness of the LM aquifer ranges between 30 and $70 \mathrm{~m}$. The Specific capacity of both aquifers ranges between 13.43 and $870 \mathrm{lpm} / \mathrm{m}$ of drawdown and the transmissivity value ranges from 11 to $1202 \mathrm{~m}^{2} /$ day. The storativity is in the order of $4.81 \times 10^{-1}$ to $4.40 \times 10^{-10}$ irrespective of aquifers. Ground water extractions are by filter point wells, tube wells, shallow wells and infiltration wells irrespective of aquifers. The PQS aquifers consist of sand, gravel and clay. The aquifer is more clayey towards the east and south eastern part of the study area, excluding the coastal section of beach sands. The depth to shallow aquifers fluctuates between 3 and $35 \mathrm{~m}$. In LM aquifers, the depth ranges

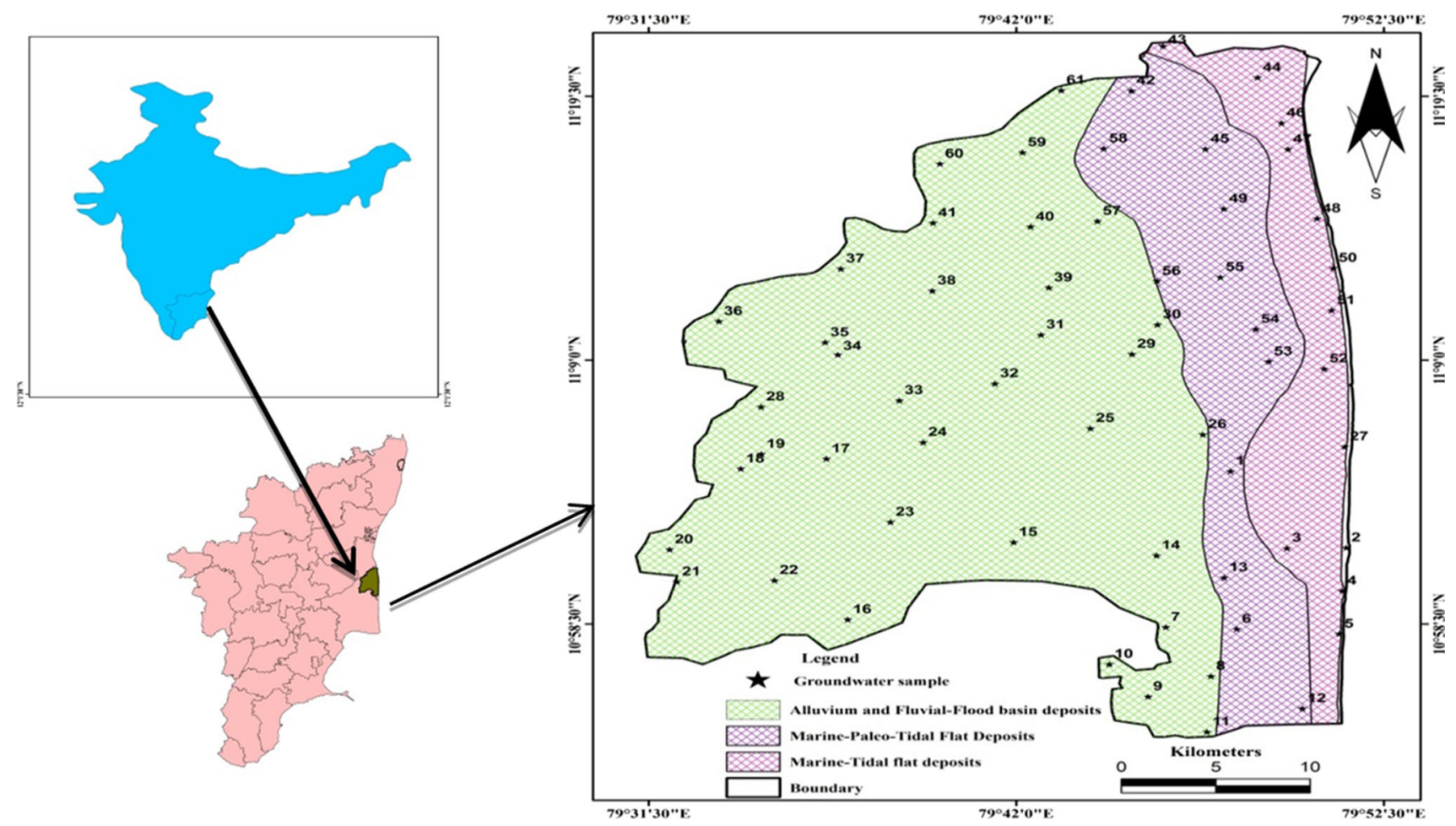

Fig. 1 Location, geology and groundwater sampling points of the study area 
between 80 and $100 \mathrm{~m}$. The piezometric head varies between 4.43 and $12.25 \mathrm{~m} \mathrm{bgl}$ during pre monsoon and $2.10-10.20 \mathrm{~m} \mathrm{bgl}$ during post monsoon with an average fluctuation of $0.47-0.56 \mathrm{~m} /$ year in both the aquifer systems. The entire area is a pediplain with gentle slope due east and southeast. A total of 61 observation wells were selected to monitor groundwater levels along with chemical analysis of groundwater. The groundwater altitude contours during the Pre Monsoon (PRM) and Post Monsoon (POM) seasons show the groundwater flow direction towards Bay of Bengal with groundwater velocity of $0.057 \mathrm{~m} /$ day (Fig. 2).

\section{Drainage pattern}

The major river Cauvery drains Bay of Bengal in the study area. The five tributaries of river Cauvery like nandhalar, uppanar, arasalar, nattar and thirumullairajan drains the study area.

\section{Materials and methods}

A total of 122 groundwater samples were collected using acid cleaned $500 \mathrm{~mL}$ polyethylene bottles during PRM and POM seasons (Fig. 1). Samples were analyzed for $\mathrm{pH}$, electrical conductivity (EC), Total dissolved solids (TDS), major ions $\mathrm{Ca}^{2+}, \mathrm{Mg}^{2+}, \mathrm{Na}^{+}, \mathrm{K}^{+}, \mathrm{HCO}_{3}^{-}, \mathrm{Cl}^{-}, \mathrm{SO}_{4}^{-2}, \mathrm{~F}^{-}$ and $\mathrm{NO}_{3}$ using standard procedures (APHA 2005; Ramesh and Anbu 1996).

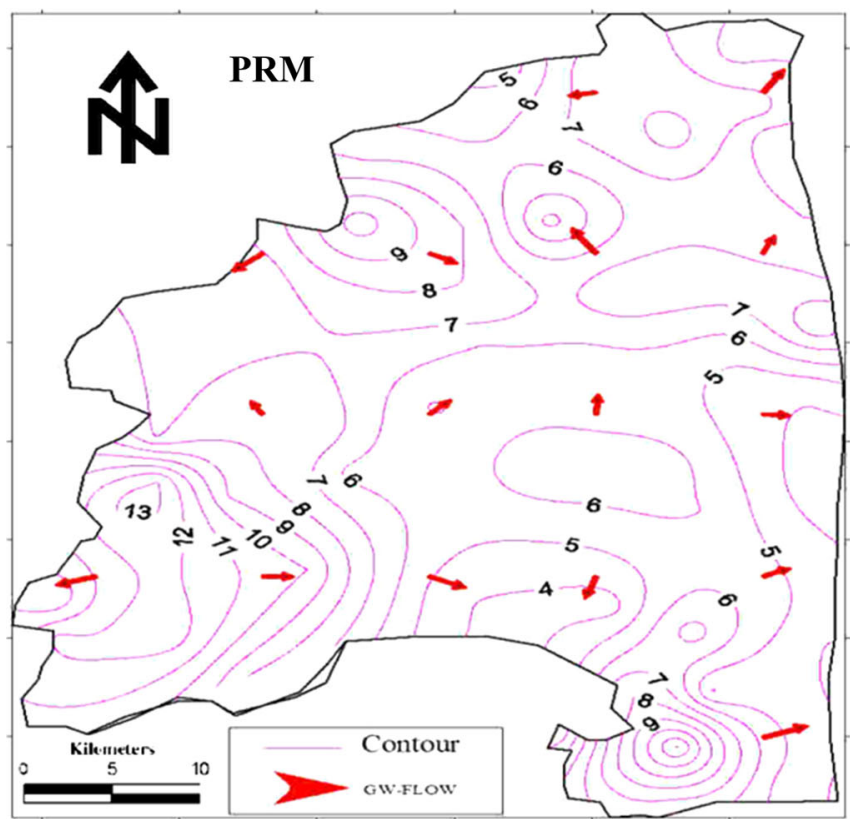

\section{Numerical modeling}

Numerical models simulate groundwater flow and also combine solute transport with groundwater flow. In coastal aquifers, numerical model simulation is problematic due to variation in water density and variation in concentration of chemical species in the water environment within the modeled area (Gaaloul et al. 2012). To rectify the same, two approaches as proposed by (Reilly 1993) are used to simulate freshwater-saltwater interactions. The first approach treats the freshwater and saline water as immiscible and separated by a sharp interface. In the next, the freshwater and saline water are treated as unique fluid by considering the salinity of the fluid. Multi-component reactive transport models and variable density flow models are successfully applied to govern the groundwater systems. Many researches focused on multi component modeling techniques for groundwater throughout the globe. The models include PHREEQC-II (Parkhurst and Appelo 1999), PHAST (Parkhurst et al. 1995), HydroBioGeoChem (Yeh et al. 1998), MODFLOW/MT3DMS based models such as RT3D (Clement et al. 1998) and PHT3D (Prommer et al. 2003). Other models developed for solute transport species include SUTRA, (Voss 1984), METROPOL (Sauter et al. 1993), FEMWATER (Lin et al. 1996), HST3D, (Kipp Jr 1997), NAMMU (Herbert et al. 1988), FEFLOW, (Kolditz et al. 1998) and MOCDENS3D, (Oude Essink GHP 2001).

Fig. 2 Groundwater elevation contours (in m) during PRM and POM seasons 


\section{Seawat}

The SEAWAT code proposed by Guo and Bennett (1998a, b), to simulate groundwater flow and saltwater intrusion in the coastal environments. The present Seawat code (Bear 2005; Langevin et al. 2003) utilizes the modified version of Modflow (McDonald and Harbaugh 1988) to solve the variable density, groundwater flow equation and MT3D (Zheng 1990) to solve the solute transport equation. To minimize the complexity and runtimes, the SEAWAT code uses one step lag between solution of flow and transport. In SEAWAT, the MT3D module simulates for a particular time step followed by MODFLOW (Harbaugh et al. 2000) for the same time step to calculate the density of groundwater. In the next step, solutions from the MODFLOW are used by MT3DMS (Zheng and Wang 1999) to solve the transport equation. In most of the simulations, one step lag does not introduce significant error and if so, the error can be reduced by decreasing the length of the time step used for the groundwater simulation. The reason for selecting the SEAWAT code for the present study is the utility of MT3D to solve the mass transport equation. The MT3D solves the transport equation using the method of characteristics (MOC) methods, since it is ideal for reducing numerical dispersion. Another advantage of using SEAWAT is that it uses the universal acceptable modeling codes including MODFLOW and MT3D. The basic code developed by combined groundwater flow and solute transport model using MODFLOW and MT3DMS flow sequences as:

$$
\begin{aligned}
& \frac{\partial}{\partial x}\left(\rho \mathrm{K} f \chi+\left[\frac{\partial h f}{\partial x}+\frac{\rho-\rho f}{\rho f} \frac{\partial \mathrm{Z}}{\partial x}\right]\right) \\
& +\frac{\partial}{\partial \beta}\left(\rho \mathrm{K} f \beta\left[\frac{\partial h f}{\partial \beta}+\frac{\rho-\rho f}{\rho f} \frac{\partial Z}{\partial \beta}\right]\right) \\
& +\frac{\partial}{\partial \gamma}\left(\rho \mathrm{K} f \gamma\left[\frac{\partial h f}{\partial \gamma}+\frac{\rho-\rho f}{\rho f} \frac{\partial \mathrm{Z}}{\partial \gamma}\right]\right) \\
& \quad=\rho \mathbb{S} f \rho f \frac{\partial h f}{\partial t}+\theta \frac{\partial \rho}{\partial C} \frac{\partial C}{\partial t}-\rho q s
\end{aligned}
$$

where $\alpha, \beta$ and $\gamma$ are the orthogonal coordinate axes allied along the directions of permeability; $\mathrm{K}_{\mathrm{f} \alpha}, \mathrm{K}_{\mathrm{f} \beta}$ and $\mathrm{K}_{\mathrm{f} \gamma}$ are the freshwater hydraulic conductivities along the three coordinate directions in $\left(\mathrm{LT}^{-1}\right) ; \rho$ is the fluid density in $\left(\mathrm{ML}^{-3}\right) ; \rho_{\mathrm{f}}$ is the density of freshwater in $\left(\mathrm{ML}^{-3}\right) ; \mathrm{h}_{\mathrm{f}}$ is the equivalent freshwater head in $(\mathrm{L}) ; \mathrm{Z}$ is the altitude of the middle of a model cell (L); $S_{\mathrm{f}}$ is the specific storage in terms of freshwater head $\left(\mathrm{L}^{-1}\right) ; \theta$ is effective porosity (dimensionless); $\mathrm{C}$ is the solute absorption in $\left(\mathrm{M} \mathrm{L}^{-3}\right) ; \rho^{-}$ is the density of water inflowing from a source or exit through a bowl expressed in $\left(\mathrm{M} \mathrm{L}^{-3}\right) ; \mathrm{q}_{\mathrm{s}}$ is the volumetric movement rate of sources or sinks represented in unit per volume of aquifer $\left(\mathrm{T}^{-1}\right)$; and $\mathrm{t}$ is time $(\mathrm{T})$. Head in terms of aquifer water, ' $h$ ' varies not only as pressure and elevation, but also the water density (q) varies. Thus, the concept of equivalent fresh water head $h_{f}$ is introduced to account the density difference when calculating the head as:

$h f=\rho \frac{\rho}{\rho r g}+Z$

where $\rho_{\mathrm{r}}$ is the location density, normally the density of fresh groundwater at mention chloride concentration $\left(\mathrm{M} \mathrm{L}^{-3}\right)$ and $\mathrm{p}$ is the pressure $\left(\mathrm{M} \mathrm{L}^{-1} \mathrm{~T}^{-2}\right)$.

In adding to the flow equation, another fractional differential equation is essential to describe solute-transport in the aquifer system. Solute mass is transported in porous media by the flow of groundwater (advection), molecular diffusion, and mechanical dispersion. The transport of solute mass in groundwater can be designated by ensuing partial differential equation (Zheng and Bennett 1995).

$\frac{\partial C}{\partial t}=\nabla \cdot(D \cdot \nabla C)-(\nabla \cdot v C) \frac{q s}{\theta} C s+\sum_{k=1}^{N} R k$

where $\mathrm{D}$ is the hydrodynamic diffusion coefficient $\left(\mathrm{L}^{2} \mathrm{~T}^{-1}\right)$; is the fluid velocity $\left(\mathrm{L} \mathrm{T}^{-1}\right) ; \mathrm{C}_{\mathrm{s}}$ is the solute absorption of water inflowing from sources or leaving through sinks $\left(\mathrm{M} \mathrm{L}^{-3}\right)$; and $\mathrm{R}_{\mathrm{k}}(\mathrm{k}=1 \ldots \mathrm{N})$ is the amount of solute making or decay in reaction $\mathrm{k}$ of $\mathrm{N}$ different reactions $\left(\mathrm{M} \mathrm{L}^{-3} \mathrm{~T}^{-1}\right)$. For a combined variable-density flow and solute-transport simulation, fluid density is expected to be a role only of solute concentration; the effects of pressure and temperature on fluid density are ignored (Langevin et al. 2003).

\section{Evidences for saline water intrusion}

The EC measured in locations Savadikuppam and Tarangambadi were $5355.38 \mu \mathrm{s} / \mathrm{cm}$ and $12,430 \mu \mathrm{s} / \mathrm{cm}$, respectively during PRM and POM seasons, respectively. Such, high salinity proximity to the coast raises suspicion about the source of salinity. Groundwater in general is saline, while water samples collected near Bay of Bengal showed higher salinity (Gopinath et al. 2014). Variations of TDS values during PRM and POM seasons are represented in (Fig. 2). The TDS values for the well Nos. 2, 4, 5, 8, 27 , 28, 39, 50 and 51 display very high variations during both the seasons. During PRM, TDS values were higher due to the influence of seawater intrusion (Gopinath et al. 2014). The statistics of chemical parameters for the collected groundwater samples are represented in Table 1.

Among the cation and anion, sodium and chloride dominates in groundwater samples of the study area. The chloride ions showed large variations with concentration ranging from 67.0 to $89.0 \mathrm{mg} / \mathrm{L}$ along the southern parts of the study area and to 2478.0 to $5060.0 \mathrm{mg} / \mathrm{L}$ and 
$2478.0 \mathrm{mg} / \mathrm{L}$ along the eastern parts of the study area close to Bay of Bengal during both the seasons. The seasonal growth in TDS and $\mathrm{Cl}$ ions indicate sources from dissolution of marine clays by rain water, irrigation return flows and saline water influences (Gurunadha Rao et al. 2013). Nitrate, $\mathrm{SO}_{4}^{-}$and $\mathrm{HCO}_{3}^{-}$values increases during both the seasons, might be due to the addition of sulfate by organic materials of weathered soils, sulfate leaching from fertilizers and allied anthropogenic activities (Kumar et al. 2007).

\section{Ionic cross plots}

Compositional relation between the dissolved species helps in disseminating the process involved in the origin of solutes and species in groundwater. Since $\mathrm{Na}^{+}, \mathrm{Ca}^{2+}$, $\mathrm{Mg}^{2+}, \mathrm{SO}_{4}{ }^{-}, \mathrm{HCO}_{3}{ }^{-}$and $\mathrm{Cl}^{-}$are the principal solutes in the groundwater, an investigation to correlate its origin and abundance is aided by the ionic ratio plots. The direct evidence of saline intrusion can be identifed from the ratio of $\mathrm{Mg}^{2+} / \mathrm{Ca}^{2+}$ (in epm). If the ratio is between 1 and 5 , up coning of brines and salinity are responsible for higher concentration of these ions (CAMP 2000). During $\mathrm{PRM}$, the $\mathrm{Mg}^{2+/} \mathrm{Ca}^{2+}$ ratio fluctuates between 0.045 and 3.42. A total of $42.10 \%$ samples consumed $\mathrm{Mg}^{2+/} \mathrm{Ca}^{2+}$ ratios $<1.0$ with average TDS values of $1423.6 \mathrm{mg} / \mathrm{L}$. More than $570.9 \%$ of the samples exhibited $\mathrm{Mg}^{2+} / \mathrm{Ca}^{2+}$ ratio $>1$ with higher TDS value of $8368 \mathrm{mg} / \mathrm{L}$ strongly influenced by seawater intrusion (Fig. 3a). The $\mathrm{Mg}^{2+}$ / $\mathrm{Ca}^{2+}$ ratios during POM ranged from 0.443 to 3.91 , with maximum value of 3.91 observed in well No. 2 with TDS value of $6220 \mathrm{mg} / \mathrm{l}$ located in vicinity of the ocean (Fig. 3b). During POM, $51 \%$ of the samples observed
$\mathrm{Mg}^{2+} / \mathrm{Ca}^{2+}$ ratios $>1.0$ indicating clear influence of saline water.

The governing ions of salinity are the $\mathrm{Na}^{+}$and $\mathrm{Cl}^{-}$ions and $\mathrm{Ca}^{2+}$ and $\mathrm{HCO}_{3}^{-}$are the major ions to portray the freshwater composition (Hem 1989). Higher levels of $\mathrm{Na}^{+}$ and $\mathrm{Cl}^{-}$in coastal groundwater aquifers directly indicate significant effect of saline/seawater intrusion, while significant amounts of $\mathrm{HCO}_{3}{ }^{-}$and $\mathrm{Ca}^{2+}$ reflect the contribution from water-rock interaction (Park et al. 2005). The low $\mathrm{Na}+/ \mathrm{Cl}^{-}$ratio $(<1)$ indicates seawater intrusion, whereas a high $\mathrm{Na}^{+} / \mathrm{Cl}^{-}$ratio of $>1$ indicates anthropogenic input to groundwater (Wang and Jiao 2012; Krishnakumar et al. 2013). The observed $\mathrm{Na}+/ \mathrm{Cl}^{-}$ratios during PRM and POM ranges between 0.13 and 3.45 and 0.39 and 3.42, respectively (see Fig. 4). Along the east, north and southern parts of the study area the ratios were higher during both the seasons. The $\mathrm{Na} / \mathrm{Cl}$ ratio of 0.58 signifies halite dissolution or evaporates minerals influences from marine sedimentary formations (Hounslow 1995).

\section{Model discretization and boundary conditions}

A finite-difference mesh in SEAWAT (Fig. 5) has been used to discretize the study area, by dividing into 40 rows and 40 columns for a total of 7 layers with a spacing of $200 \mathrm{~m}$. The aquifer and layer thicknes were determined by geophysical investigations and litho log data for 32 locations (Gopinath and Srinivasamoorthy 2014). In the model, layers 1, 3, 5 and 7 represent aquifers, whereas layer 2, 4, and 6 represents confining layers. No flow boundary conditions were assumed to the geographic co-ordinates of the study area (Fig. 6). The constant head boundary was
Table 1 Statistical analysis of major ions in groundwater samples during PRM and POM seasons ( $\min$ minimum, $\max$ maximum, avg average and $s t d v$ standard deviation) (all values in $\mathrm{mg} / \mathrm{L}$ except $\mathrm{pH}$ in standard units and $\mathrm{EC}$ in $\mu \mathrm{s} / \mathrm{cm}$ )

\begin{tabular}{|c|c|c|c|c|c|c|c|c|}
\hline \multirow[t]{2}{*}{ Ionic parameters } & \multicolumn{4}{|l|}{ PRM } & \multicolumn{4}{|l|}{ POM } \\
\hline & Min & Max & Avg & Stdv & Min & Max & Avg & Stdv \\
\hline $\mathrm{pH}$ & 6.00 & 8.40 & 7.39 & 0.50 & 6.33 & 8.87 & 7.54 & 0.53 \\
\hline $\mathrm{EC}$ & 251.51 & 5355.87 & 911.13 & 918.85 & 370.00 & 12,430 & 2008.19 & 2550.19 \\
\hline TDS & 392.98 & 8368.55 & 1423 & 1435 & 200.00 & 6220 & 996.29 & 1266.35 \\
\hline $\mathrm{Ca}$ & 10.00 & 416.00 & 76.21 & 80.65 & 26.00 & 198 & 77.60 & 36.28 \\
\hline $\mathrm{Mg}$ & 4.90 & 411.00 & 49.60 & 72.24 & 12.00 & 99.00 & 40.27 & 20.71 \\
\hline $\mathrm{Na}$ & 57.00 & 1950.00 & 298.54 & 361.74 & 65.00 & 1330 & 387.54 & 359.61 \\
\hline $\mathrm{k}$ & 2.00 & 218.00 & 40.58 & 50.67 & 5.00 & 418 & 80.91 & 105.68 \\
\hline $\mathrm{Cl}$ & 67.00 & 5060.00 & 544.67 & 931.62 & 89.00 & 2478 & 680.49 & 713.24 \\
\hline $\mathrm{HCO}_{3}$ & 26.40 & 567.00 & 320.08 & 120.38 & 103.00 & 587 & 302.32 & 133.55 \\
\hline $\mathrm{SO}_{4}$ & 1.50 & 430.00 & 53.64 & 77.66 & 4.50 & 367 & 62.80 & 66.14 \\
\hline $\mathrm{H}_{4} \mathrm{SiO}_{4}$ & 3.00 & 98.00 & 31.84 & 20.22 & 6.50 & 66 & 18.65 & 11.02 \\
\hline $\mathrm{PO}_{4}$ & 0.10 & 9.80 & 3.60 & 3.00 & 0.10 & 9.80 & 0.98 & 1.75 \\
\hline $\mathrm{F}$ & 0.01 & 0.98 & 0.31 & 0.22 & 0.11 & 1.20 & 0.40 & 0.29 \\
\hline $\mathrm{NO}_{3}$ & 2.00 & 145.00 & 44.98 & 34.10 & 2.67 & 103 & 44.05 & 23.18 \\
\hline
\end{tabular}



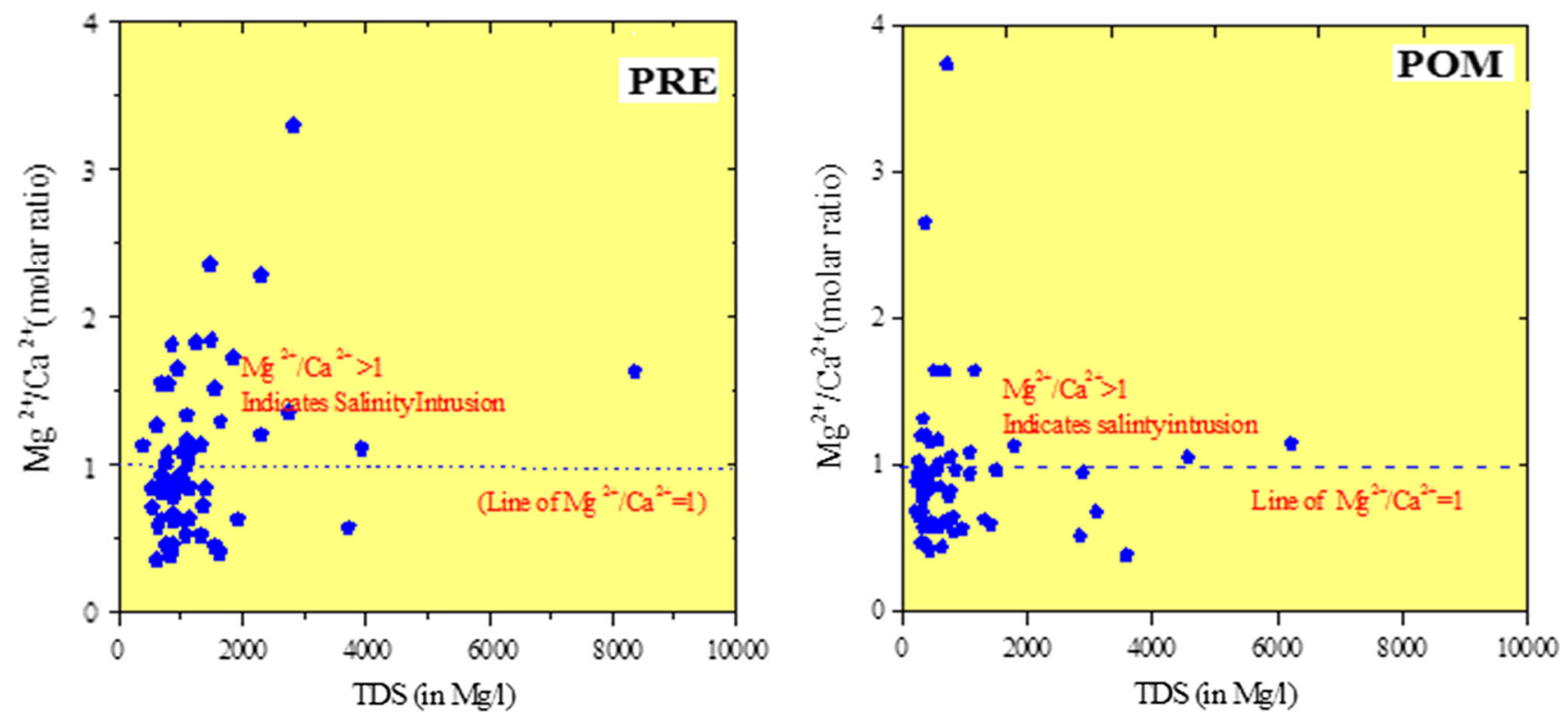

Fig. 3 Ionic cross plots for $\mathrm{Mg}^{2+/} \mathrm{Ca}^{2+}$ Vs TDS in groundwater samples during PRM and POM seasons

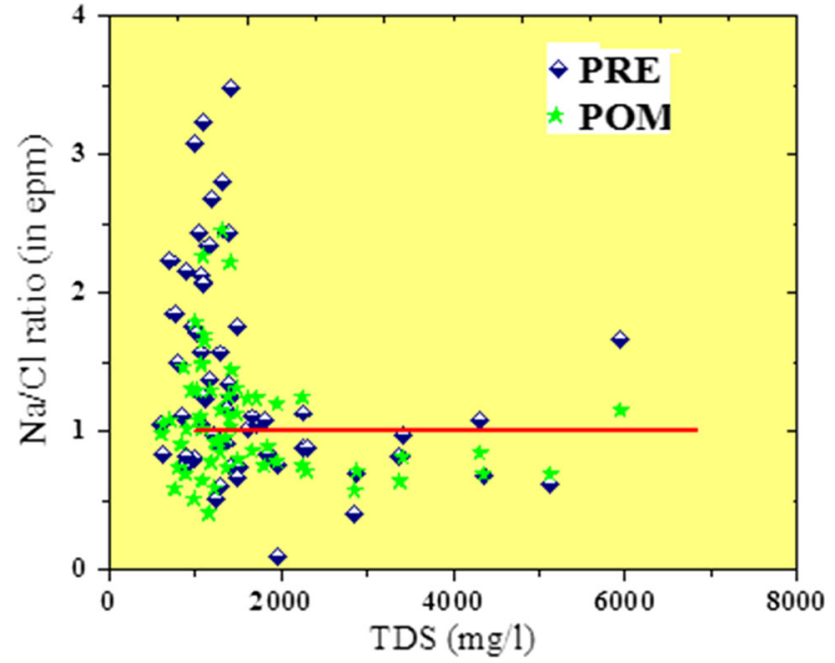

Fig. 4 Cross plots for $\mathrm{SO}_{4}{ }^{2-} / \mathrm{Cl}^{-}$Vs TDS ratios during PRM and POM seasons

assumed to the north and eastern parts of the study area and to the Cauvery River flowing in the study area. The unassigned nodes on the boundary of the mesh are considered to be no-flow nodes. The constant sea water concentration assumed for the model was $35 \mathrm{~kg} / \mathrm{m}^{3}$.

The heads assigned to the top of the study area stimulates recharge as the primary source of water to the aquifers by assuming flux type boundary condition. The flux is calculated using flow budgets by substracting sinks like evapotransipration, runoff from precipitation to assess the volume of water seeping through the soil into the aquifers. Because of the inherent uncertainty in these calculations,

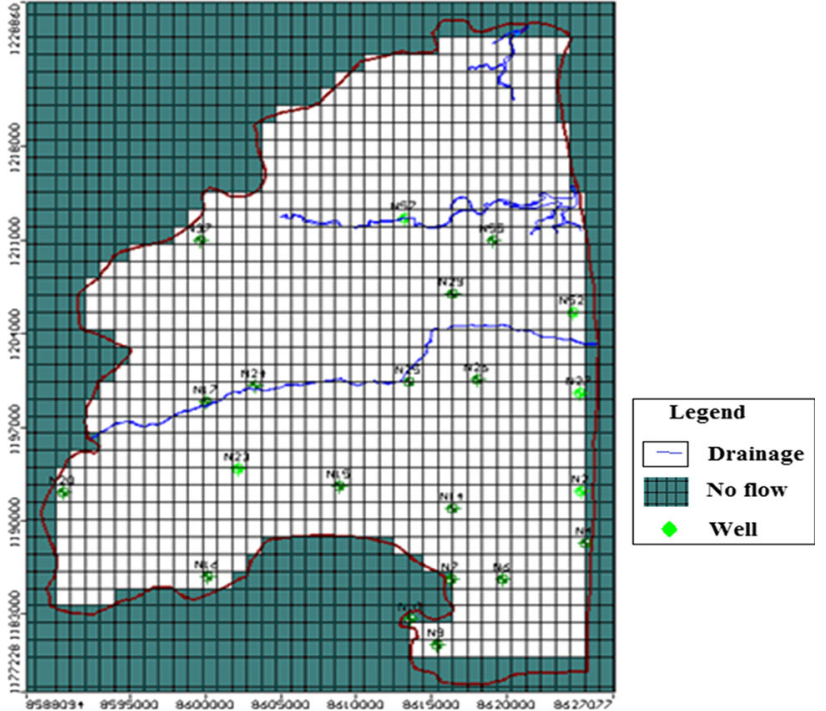

Fig. 5 Model grid, boundary condition and observation wells in the study area as extracted from SEAWAT model

recharge is often used as a calibration parameter and is varied along with hydrogeologic material properties until the model result matches with the measured aquifer conditions. The model was calibrated and validated and projected for a simulation period of 50 years.

\section{Hydrogeological parameters}

The hydraulic conductivity (Fig. 7) assumed for the fine to medium grained sandy soil was $4 \mathrm{~m} \mathrm{day}^{-1}$ (layers 1, 3) medium to coarse grained sandstone layer as $8 \mathrm{~m} \mathrm{day}^{-1}$ 
Fig. 6 Saline concentrations $(\mathrm{mg} / \mathrm{L})$ for groundwater samples at different depths using SEAWAT model
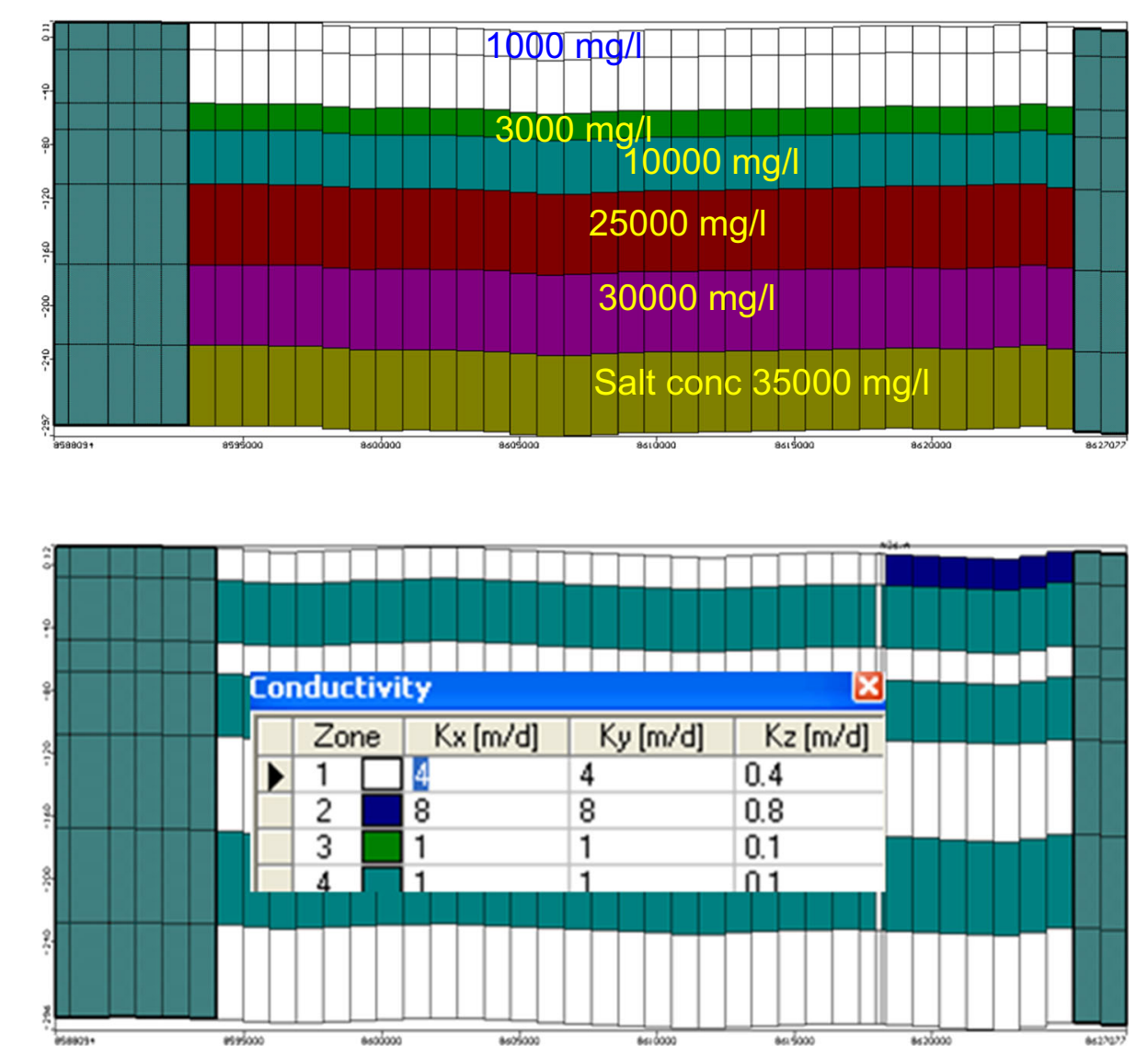

Fig. 7 Vertical cross section and conductivity for different aquifer zones identified in the study area using SEAWAT modeling code (layers 5,7 ) and to the clay layers as $1 \mathrm{~m} \mathrm{day}^{-1}$ (layers 2 , 4, and 6) CGWB (2008 and 2012).

\section{Sources and sinks}

In adding to the model boundaries, pumping wells constitute an important source/sink for groundwater into the aquifers systems of the study area. The pumping wells assumed for the present study were the currently active wells extracting water for irrigation and domestic utilities. The depths of the top and bottom of the open interval for each pump were converted to elevations based on the approximate ground surface elevation at that location. The pumping altitudes were adjusted to avoid the model from pumping in confining units. Pump rates for wells covering more than one aquifer were prorated based on the length of open interval and the estimated hydraulic conductivity of each aquifer. SEAWAT requires all pumping to be applied to the center of a cell. To accommodate these requirements, the wells were moved horizontally to nearest computational point. In SEAWAT, any well located within a grid cell, was automatically moved to the center of the cell and added to the pump rates of any other wells located in the same cell. Vertically, the pumping from each well was divided among the cells or nodes in the aquifer according to the vertical location of the open interval of the well.

\section{Calibration and model validation}

Model calibration is the process of varying model input parameters within a reasonable range until the model output matches observed conditions within some acceptable error criteria. This calibration can be either for steady-state or transient conditions. Steady-state model simulations eliminate the time terms in the governing equations and provide a snap-shot of the hydraulic conditions in a stable aquifer system. An inherent assumption with this type of simulation is that the system has achieved an equilibrium condition. Steady state results are also commonly used as initial conditions for subsequent transient simulations. For models that are affected by a variety of constantly changing stresses, transient calibration is necessary to ensure that the model is providing a reliable representation of the system (USACE 2011). The steady state and transient calibration/validation descriptions are for the final calibration of the SEAWAT model. 
Fig. 8 Up coning phenomena around the pumping wells after 50 years of pumping

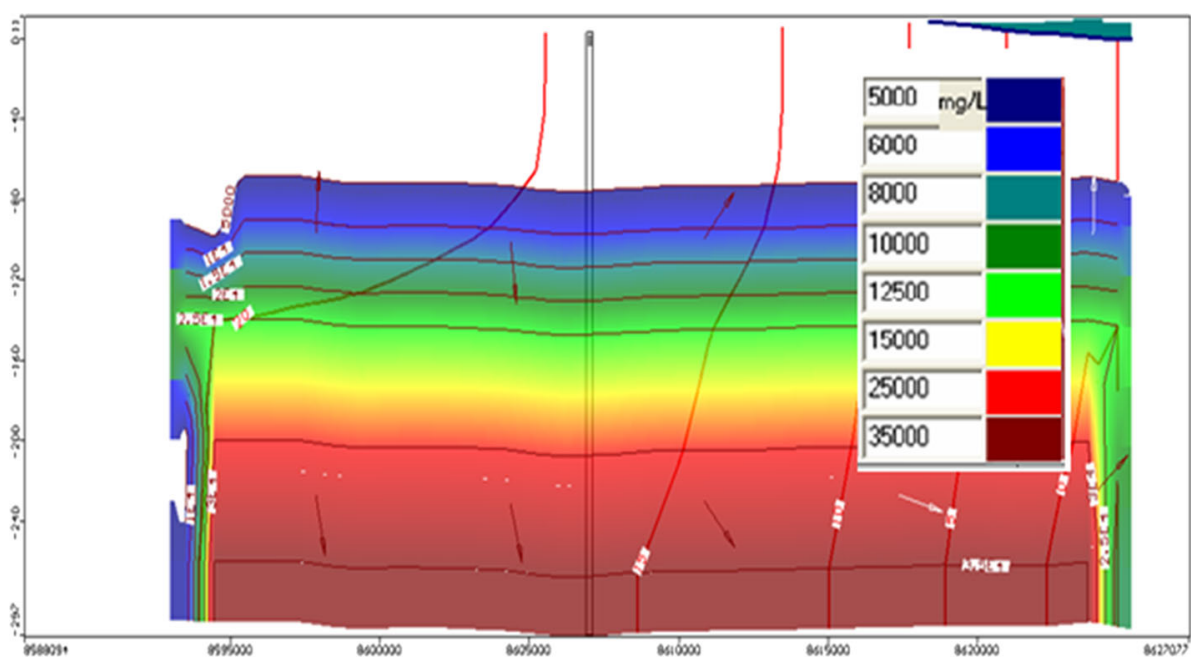

\section{Discussions}

Groundwater flow model calibration has been attempted by considering the two key parameters (hydraulic conductivity and recharge rates). The model has been calibrated for hydraulic head to 61 observation wells by considering the variations during the PRM season. The observed hydraulic head agrees with the computed values of SEAWAT. The aquifer hydraulic conductivity decreases with depth due to the overlying load on the aquifer material (Davis and Deweist 1966; De Marsily 1986). The conductivity of the clay layers $(2,4$, and 6 layers) was reduced to $0.52,0.41$, and $0.65 \mathrm{~m} \mathrm{day}^{-1}$ from top to bottom from the initial value of $1 \mathrm{~m} \mathrm{day}^{-1}$, whereas conductivity of the sandy soil layers was increased to $4.1,3.9$, and $4.2 \mathrm{~m} \mathrm{day}^{-1}$ from approximate $4 \mathrm{~m} \mathrm{day}^{-1}$ from top to bottom ( 1 and 3 layers) and 7.8 and 8.1 sandstone layer was resolute to approximately $8 \mathrm{~m} \mathrm{day}^{-1}$ (layers 5 and 7). The groundwater recharge were also raised from 278 to $284 \mathrm{~mm} \mathrm{year}^{-1}$ for proper validation of the model data.

The calculated model was then simulated for the next 50 years using the same hydrological parameters to assess the extent of saltwater intrusion due to pumping phenomenon in the observation wells in the study area. Upconing phenomena were predicted for the years 2014, 2024, 2034, 2044, 2054 and 2064. The simulations indicated that the phenomena of upconing can spread up to $725 \mathrm{~m}^{2}$ near by the bore well for the year 2056. The cone of depression is mainly due to bore well point groundwater withdrawal and the groundwater velocity vectors do not show any lateral flow from Bay of Bengal. Hence up coning phenomenon found to be active in the study area due to the over extraction of groundwater along the coastal stretches of the study area. This was also aided by increase in $\mathrm{Cl}^{-}$up to $8000 \mathrm{mg} / \mathrm{L}$ (Fig. 8). Comparison of up coning during 2014 with 2026 indicates $400 \mathrm{~m}^{2}$ of the groundwater regimes around the bore well might be influenced by elevated salinity. Further, the aquifer system which is being separated by the clay layer (the second layer in the model) significantly segregates the vertical flow during pumping. As a result, the shallow aquifer zone (the first layer in the model) contributes to groundwater being pumped. Therefore, there was significant impact of groundwater pumping on the shallow aquifers around the pumping wells.

\section{Conclusions}

The effect of seawater intrusion on fresh groundwater in coastal areas requires thorough examination, especially when the withdrawal for water supply in the coastal areas increases. An attempt has been made in the present study area to demarcate the saline influences by hydrochemistry and modeling approach. The groundwater flow directed toward the Bay of Bengal with a steep groundwater gradient. Water chemistry data signifies higher EC and TDS during both the seasons along the coastal regions suggesting saline water traces. Sodium and Chloride were found to be dominating along the coastal regions. Higher nitrate and sulphate suggests evidences of fertilizer influences. The ionic ratio plots suggest influence of saline water intrusion along the coasts and significance of rock water interaction noted along the NW parts of the study area. The SEAWAT model calibrated and validated for the present study area suggests the up coning of saline water which aided in increase of Chloride ions up to $8000 \mathrm{mg} / \mathrm{l}$ due to the pumping activities from the observation wells. From the modeling studies significant impact up to an extent of $400 \mathrm{~m}^{2}$ from the pumping wells have been identified to be influenced by salinity and the situation likely to worsen further in view of present pumping activities. 
Acknowledgments The corresponding author acknowledges University Grants Commission (UGC), India for the financial support through major research project (Grant No. 41-1036/2012 (SR) dated 01/07/2012). The first author acknowledges UGC for project fellow position. The authors thank VVS.Gurunadha Rao, Project Advisor, (CSIR) - National Geophysical Research Institute (NGRI) for his help and support in modeling studies.

\section{References}

Abd-Elhamid HF, Javadi AA (2011) A density-dependant finite element model for analysis of saltwater intrusion in coastal aquifers. J Hydrol 401:259-271

APHA (2005) Standards methods for the examination of water and wastewater, 21st edn. APHA, Washington DC

Bakker M, Oude Essink GHP, Langevin CD (2004) The rotating movement of three immiscible fluids-a benchmark problem. J Hydrol 287:270-278

Bear J (2005) Seawater intrusion into coastal aquifers. In: Anderson MG (ed) Encyclopedia of hydrological sciences. Wiley, Devon

Bobba AG (1993) Mathematical models for saltwater intrusion in coastal aquifers. Water Resour Manag 7:3-37

CAMP (2000) Integrated aquifer management plan: final report. Gaza coastal aquifer management program. Metcalf and Eddy Inc. in cooperation with the Palestinian Water Authority (PWA).United States Agency for International Development, USAID Contract No. 294-C-00-99-00038-00

CGWB (1993) Groundwater resources and devolepment prespect karaikkal regions union tertiary of Pondicherry region, India. $1-20$

CGWB (2008) Ground water resources and development prospects in district Groundwater brochure Nagapattinam District Tamil Nadu. Techn Report 1-20

CGWB (2012) Ground water resources and development prospects in district groundwater brochure Nagapattinam district Tamil Nadu. UnPuplished Report 1-24

Clement TP, Sun Y, Hooker BS, Petersen JN (1998) Modeling multispecies reactive transport in ground water. Ground Water Monit Remediat 18(2):79-92

Davis SN, Deweist RJM (1966) Hydrogeology. Wiley, New York

De Marsily G (1986) Quantitative hydrogeology: groundwater hydrology for engineers. Academic Press Inc, London

Ding Fei, Yamashita Takao, Lee Han Soo, Pan Jun (2014) A modelling study of seawater intrusion in the liao dong bay coastal plain, china. J Mar Sci Technol 22(2):103-115

Gaaloul N, Pliakas F, Kallioras A, Schuth C, Marinos P (2012) Simulation of seawater intrusion in coastal aquifers: 45-years exploitation in an Eastern coast aquifer in NE Tunisia. Hydrol J 6:31-44

Gopinath S, Srinivasamoorthy K (2014) Geophysical VES approach for seawater intrusion assessment in Nagapattinam and Karaikal coastal aquifers, India. COASTAL Resour Manag Strateg Spat Technol 13(14):50-56

Gopinath S, Srinivasamoorthy K, Prakash R (2014) Hydrochemical investigations for identification of groundwater salinization sources in Nagapattinam and Karaikal regions, Southern India. Environ GeoChim Acta 1(2):153-160

Guo W, Bennett GD (1998a) Simulation of saline/fresh water flows using MODFLOW. In Proceedings of MODFLOW'98 Conference at the International Ground Water Modeling Center, Golden, Colorado: Colorado School of Mines 1:267-274

Guo W, Bennett GD (1998b) SEAWAT Version 1.1: a computer program for simulations of groundwater flow of variable density. Fort Myers, Florida: Missimer International Inc
Guo W, Langevin CD (2002) User's guide to SEAWAT: a computer program for simulation of three dimensional variable density groundwater flows. US Geol Surv TWRI Book 6:7-79

Gurunadha Rao VVS, Tamma Rao G, Surinaidu L, Mahesh J, Mallikharjuna Rao TS, Mangaraja Rao B (2013) Assessment of geochemical processes occurring in ground waters in the coastal alluvial aquifer. Environ Monit Assess 185(10):8259-8272

Harbaugh AW, Banta ER, Hill MC, McDonald MG (2000) MODFLOW-2000, the US. Geological Survey modular ground-water model-user guide to modularization concepts and the groundwater flow process: US. Geological Survey open-file report, 00-92: 121

Hem JD (1989) Study and interpretation of the chemical characteristics of natural water. U.S.G.S. Water-Supply Paper, No 2254. US Government Printing Office, Washington

Herbert AW, Jackson CP, Lever DA (1988) Coupled groundwater flow and solute transport with fluid density strongly dependent on concentration. Water Resour Res 24(10):1781-1795

Hounslow AW (1995) water quality data analysis and interpretation. Lewis, Boca Raton

Kipp Jr KL (1997) Guide to the revised heat and solute transport simulator: HST3D—version 2. In: U.S. Geological Survey Water-Resources Investigations Report 97-4157, p 149

Kolditz O, Ratke R, Diersch HJ, Zielke W (1998) Coupled groundwater flow and transport: 1 . Verification of variable density flow and transport models. Adv Water Res 21(1):27-46

Kopsiaftis G, Mantoglou A, Giannoulopoulos P (2009) Variable density coastal aquifer models with application to an aquifer on Thira Island. Desalination 237:65-80

Krishnakumar P, Lakshumanan C, Pradeep Kishore V, Sundararajan M, Santhiya G, Chidambaram S (2013) Assessment of groundwater quality in and around Vedaraniyam, South India. Environmental Earth Science http://dx.doi.org/ 10.1007/s12665-0132626-2

Kumar M, Kumari K, Ramanathan AL, Saxena R (2007) A comparative evaluation of groundwater suitability for irrigation and drinking purposes in two agriculture dominated districts of Punjab India. J Environ Geol 53(3):553-574

Langevin CD, Shoemaker WB, Guo W (2003) MODFLOW-2000, the US. Geological Survey Modular Ground-Water Model-Documentation of the SEAWAT-2000 version with the Variable density flow process (VDF) and the integrated MT3DMS Transport Process (IMT).USGS Open-File Report 03-426

Lin HC, Richards DR, Yeh GT, Cheng JR, Cheng HP, Jones NL (1996) FEMWATER: a three-dimensional finite element computer model for simulating density-dependent flow and transport. Technical report HL-96. USA: US Army Engineer Waterways Experiment Station

McDonald MG, Harbaugh AW (1998) A modular three dimensional finite- difference ground-water flow model. Book 6 USA: US. Geological survey techniques of water resources investigations

Oude Essink GHP (2001) Saltwater intrusion in 3D large-scale aquifers: a Dutch case. PhysChem Earth 26(4):337-344

Park SC, Yun ST, Chae GT, Yoo I, Shin KS, Heo CH (2005) Regional hydrochemical study on salinization of coastal aquifers, western coastal area of South Korea. J Hydrol 313(3-4):182-194

Parkhurst DL, Appelo CAJ (1999) User's Guide to PHREEQC—a computer program for speciation, reaction-path, 1D-transport, and inverse geochemical calculations. (version 2) Technical Report 99-4259. USA: US geological survey

Parkhurst DL, Engesgaard P, Kipp KL (1995) Coupling the geochemical model PHREEQC with a 3D multi-component solute transport model. Paper presented at Fifth Annual V.M. Goldschmidt Conference. USA: geochemical society, Penn State University, University park 
Prommer H, Barry DA, Zheng C (2003) ODFLOW/MT3DMSbased reactive multicomponent transport modeling. Ground Water 41(2):247-257

Ramesh R, Anbu M (1996) Chemical methods for analysis environmental analysis-water and sediment. Macmillan India Ltd., p 1-61

Reilly TE (1993) Analysis of groundwater systems in freshwatersaltwater environments. In: Alley WM (ed) Regional groundwater quality. Van Nostr and Reinhold, New York, pp 443-469

Sauter FJ, Leijnse A, Beusen AHW (1993) METROPOL user's guide, report number 725205003. National Institute of Public Health and Environmental Protection, Bilthoven

Sindhu G, Ashitha M, Jairaj PG, Raghunath Rajesh (2012) Modelling of coastal aquifers of Trivandrum. Procedia Eng 38:3434-3448

Surinaidu L, GurunadhaRao VVS, Mahesh J, Rajendra Prasad P, TammaRao G, Sarma VS (2014) Assessment of possibility of saltwater intrusion in the central Godavari delta region. Reg Environ Change, Southern India. doi:10.1007/s10113-014-0678-9

USACE (2011) Final groundwater model calibration report -Aquifer storage and recovery regional modeling study, Report prepared for USACE-SAJ and SFWMD by USACE-NAP, p 1-61

Voss CI (1984) A finite-element simulation model for saturated unsaturated, fluid-density-dependent ground-water flow with energy transport or chemically reactive single-species solute transport US. Geol Surv, USA
Wang Y, Jiao JJ (2012) Origin of groundwater salinity and hydrogeochemical processes in the confined quaternary aquifer of the pearl river delta China. J Hydrol 438-439:112-124

Werner AD, Simmons CT (2008) Impact of sea-level rise on sea water intrusion in coastal aquifers. Ground Water 47(2):197-204

Xue Y, Xie C, Wu J (1999) Seawater intrusion and research on movement of interface of fresh-saline water. Nanjing University Press, Nanjing

Yeh GT, Salvage KM, Gwo JP, Zachara JM, Szecsody JE (1998) HYDROBIOGEOCHEM: a coupled model of HYDROlogic transport and mixed BIOGEOCHEMical kinetic/equilibrium reactions in saturated-unsaturated media. Oak Ridge National Laboratory, Center for Computer Sciences, Oak Ridge

Zheng C (1990) MT3D, a modular three-dimensional transport model for simulation of advection, dispersion and chemical reactions of contaminants in groundwater systems, report to the US Environmental Protection Agency Robert S. Kerr Environmental Research Laboratory, Ada

Zheng C, Bennett GD (1995) Applied contaminant transport modeling: theory and practice. Van Nostrand Reinhold, New York

Zheng C, Wang PP (1999) MT3DMS-A modular three dimensional multi species transport model for simulation of advection, dispersion and chemical reactions of contaminants in groundwater systems; Documentation and user's guide: US Army Corps of Engineers Contract Report SERDP-99-1 